\title{
Nematode modulation of inflammatory bowel disease
}

\author{
Rose A. K. Whelan • Susanne Hartmann • \\ Sebastian Rausch
}

Received: 6 October 2011 / Accepted: 11 October 2011 /Published online: 17 November 2011

(C) The Author(s) 2011. This article is published with open access at Springerlink.com

\begin{abstract}
Inflammatory bowel disease (IBD) is a chronic disease arising due to a culmination of genetic, environmental, and lifestyle-associated factors and resulting in an excessive pro-inflammatory response to bacterial populations in the gastrointestinal tract. The prevalence of IBD in developing nations is relatively low, and it has been proposed that this is directly correlated with a high incidence of helminth infections in these areas. Gastrointestinal nematodes are the most prevalent parasitic worms, and they efficiently modulate the immune system of their hosts in order to establish chronic infections. Thus, they may be capable of suppressing unrelated inflammation in disorders such as IBD. This review describes how nematodes, or their products, suppress innate and adaptive pro-inflammatory immune responses and how the mechanisms involved in the induction of anti-nematode responses regulate colitis in experimental models and clinical trials with IBD patients. We also discuss how refinement of nematodederived therapies should ultimately result in the development of potent new therapeutics of clinical inflammatory disorders.
\end{abstract}

Keywords Inflammatory bowel disease · Crohn's disease . Immune modulation - Gastrointestinal nematodes .

Nematode therapy

Handling Editor: David Robinson

R. A. K. Whelan · S. Hartmann · S. Rausch $(\bowtie)$

Department of Molecular Parasitology,

Humboldt University of Berlin,

10115 Berlin, Germany

e-mail: sebastian.rausch@hu-berlin.de

\author{
Abbreviations \\ AAM Alternatively activated macrophage \\ CD Crohn's disease \\ DC Dendritic cell \\ DSS Dextran sodium sulfate \\ DNBS Dinitrobenzene sulfonic acid \\ IBD Inflammatory bowel disease \\ IFN Interferon \\ ES Excretory/secretory \\ Foxp3 Forkhead box P3 \\ IL Interleukin \\ mLN Mesenteric lymph node \\ MPO Myeloperoxidase \\ RELM Resistin-like molecule \\ TGF Transforming growth factor \\ Th T helper cell \\ TLR Toll-like receptor \\ TNBS Trinitrobenzenesulfonic acid \\ TNF Tumor necrosis factor \\ Treg Regulatory $\mathrm{T}$ cell \\ TSLP Thymic stromal lymphopoietin \\ UC Ulcerative colitis
}

\section{Introduction}

Inflammatory bowel disease (IBD) is a chronic inflammatory disorder that manifests in a dysregulated mucosal immune response against intestinal bacteria. Human IBD can be classified into two main characteristic forms: ulcerative colitis (UC) and Crohn's disease (CD). UC generally involves $\mathrm{T}$ helper cell type 2 (Th2) and Th17driven inflammation, leading to superficial ulceration of the 
colon. CD is characterized by Th1-type-driven inflammation that leads to isolated, often transmural lesions and may involve the entire gastrointestinal tract (Xavier and Podolsky 2007). IBD patients show relapsing and remitting disease that is often lifelong.

The pathogenesis of IBD still remains incompletely understood, but the complex etiology involves multiple genetic, immunological, and environmental factors. The intestinal microbiota is central for the initiation of IBD development. Pathogenic or commensal bacteria trigger microbial sensing systems, which initiate pro-inflammatory responses by innate cells, such as dendritic cells and macrophages producing interleukin (IL)-12/23, tumor necrosis factor alpha (TNF- $\alpha$ ), IL-6, IL-1 $\beta$, reactive oxygen species, and nitric oxide which leads to disrupted epithelial barrier function in susceptible individuals. The following activation of the adaptive immune system leads to the strong production of inflammatory cytokines (interferon gamma (IFN- $\gamma$ ), TNF- $\alpha$, and IL-17A) by T helper (Th) cells, which constitute the dominant force driving chronic inflammation in IBD patients (Xavier and Podolsky 2007). Genetic inheritance is a strong component of IBD development; roughly 100 gene loci are currently linked to IBD susceptibility (Anderson et al. 2011), and up to a 20-fold increased risk of developing $\mathrm{CD}$ has been reported if a firstdegree relative is already afflicted. Predisposing polymorphisms linked to IBD development have been found in genes commonly associated with immune reactions to the intestinal flora and gut homeostasis. IBD-associated polymorphisms affect pro-inflammatory and regulatory cytokines (e.g., $T N F, I F N G$, and $I L 10$ ), their receptors (e.g., $I L 23 R$ and $I L 1 R 2$ ) as well as signaling pathways (e.g., $S M A D 3)$ and antigen presentation molecules or epithelial innate defense factors (van Heel et al. 2002; Anderson et al. 2011; Duerr et al. 2006; Franke et al. 2010). Finally, lifestyle-associated factors like diets rich in fat and animal protein as well as smoking increase the risk of developing IBD (Hou et al. 2011).

The prevalence of IBD, allergies, and autoimmune disorders is increased in industrialized nations in comparison to developing countries. This correlation has been explained by the so-called "hygiene hypothesis," which suggests that the decreased exposure to previously common infections that have subsequently been reduced as a result of increased hygiene in the western world may result in increased incidence of autoimmune and inflammatory disorders (Strachan 1989). In line with this concept, parasitic worm infections are efficiently controlled by antihelminthic drugs and hygiene practices in developed countries, and their eradication coincides with an increase in the development of immune disorders, including IBD (Elliott et al. 2000). The vertebrate immune system has coevolved under constant attack from parasitic helminths, leading to a balance between host protective inflammatory mechanisms controlling worm infections and immune modulation conducted by the parasites (Fumagalli et al. 2009; Maizels et al. 2004). The immune system of individuals living in an environment lacking these parasites may be insufficiently trained and modified and thus develop aberrant immune reactions to common antigens or commensal bacteria. Experimental infections with helminths or treatment with immunomodulatory worm-derived components has shown that helminths can efficiently suppress unrelated immune reactivity, including colitis. While current anti-inflammatory and immunosuppressive IBD therapies may induce and maintain remission, not all patients respond to such therapies and no long-term curative drug therapy has been developed to date. Thus, studies in mouse models and human trials with IBD patients showing preventive and therapeutic effects of helminths have generated substantial interest. For the purpose of this review, we will focus on anti-colitic effects of gastrointestinal nematodes, a diverse phylum with a large body of research regarding modulation of the host's immune response.

\section{Immune modulation by nematodes: the diverse targets}

The induction of highly skewed T helper cell type 2 (Th2) responses to nematodes is associated with the efficient control of worm infections (see Table 1). However, nematodes have coevolved efficient immune evasion mechanisms enabling their prolonged survival and reproduction in the host (see Fig. 1). The modulation of the immune response is seen as an evolutionary adaptation that is also beneficial for the host as overt immunopathology and thereby damage to the host is avoided (Maizels et al. 2004). Nematode-induced immune modulation also has the ability to suppress bystander responses to unrelated antigens, and nematode infections have also been shown to suppress unrelated inflammation such as airway hyperreactivity (Hartmann et al. 2009; Kitagaki et al. 2006; Wilson et al. 2005). It is unlikely that the potent suppression of such inflammatory processes is the consequence of one dominant modulation pathway, but rather results from the interference with multiple steps of elicited immune responses.

Indeed, live nematodes and their excretory/secretory (ES) products have been shown to modulate a plethora of innate and adaptive immune cells (see Fig. 1). Nematode infections enhance the induction of dendritic cells (DCs) supporting the outgrowth of regulatory $\mathrm{T}$ cell populations and production of anti-inflammatory IL-10 in the intestine and gut-draining lymph nodes ( $\mathrm{Li}$ et al. 2011). Macro- 
Table 1 Overview of murine nematode infection models applied in the context of IBD

\begin{tabular}{|c|c|c|c|c|}
\hline Organism & Model relevance & Location of infection & Th2-inducing capacity & Infection persistence \\
\hline $\begin{array}{l}\text { Heligmosomoides } \\
\text { polygyrus }\end{array}$ & $\begin{array}{l}\text { Chonic human intestinal } \\
\text { nematode infections }\end{array}$ & $\begin{array}{l}\text { Proximal small intestine, transiently tissue } \\
\text { penetrating (L4), adults reside in lumen }\end{array}$ & ++ , highly polarized & $\begin{array}{l}\text { Chronic infection in most } \\
\text { mouse strains for weeks/months }\end{array}$ \\
\hline Trichuris muris & $\begin{array}{l}\text { Human whipworm } \\
\text { infections }\end{array}$ & $\begin{array}{l}\text { Caecum and upper colon, intraepithelial } \\
\text { with distal end in lumen }\end{array}$ & $\begin{array}{l}+/++, \text { strongly } \\
\text { dependent on mouse } \\
\text { strain }\end{array}$ & $\begin{array}{l}\text { Depends on infective dose and mouse } \\
\text { strain, mostly expelled within } 3 \text { weeks }\end{array}$ \\
\hline $\begin{array}{l}\text { Trichinella } \\
\text { spiralis }\end{array}$ & $\begin{array}{l}\text { Infective to broad } \\
\text { spectrum of mammals }\end{array}$ & $\begin{array}{l}\text { Intraepithelial in small intestine, newborn } \\
\text { infective larvae migrate into muscle tissue }\end{array}$ & ++ & $\begin{array}{l}\text { Rodents expel adults within } 2 \text { weeks; } \\
\text { long survival of infective L } 3 \text { in muscle } \\
\text { tissue }\end{array}$ \\
\hline
\end{tabular}

phages are a target of nematode modulation, acquiring a regulatory phenotype (Klotz et al. 2011; Schnoeller et al.
2008; Siracusa et al. 2008). T cell responses are suppressed in models of chronic nematode infections (Hartmann et al.

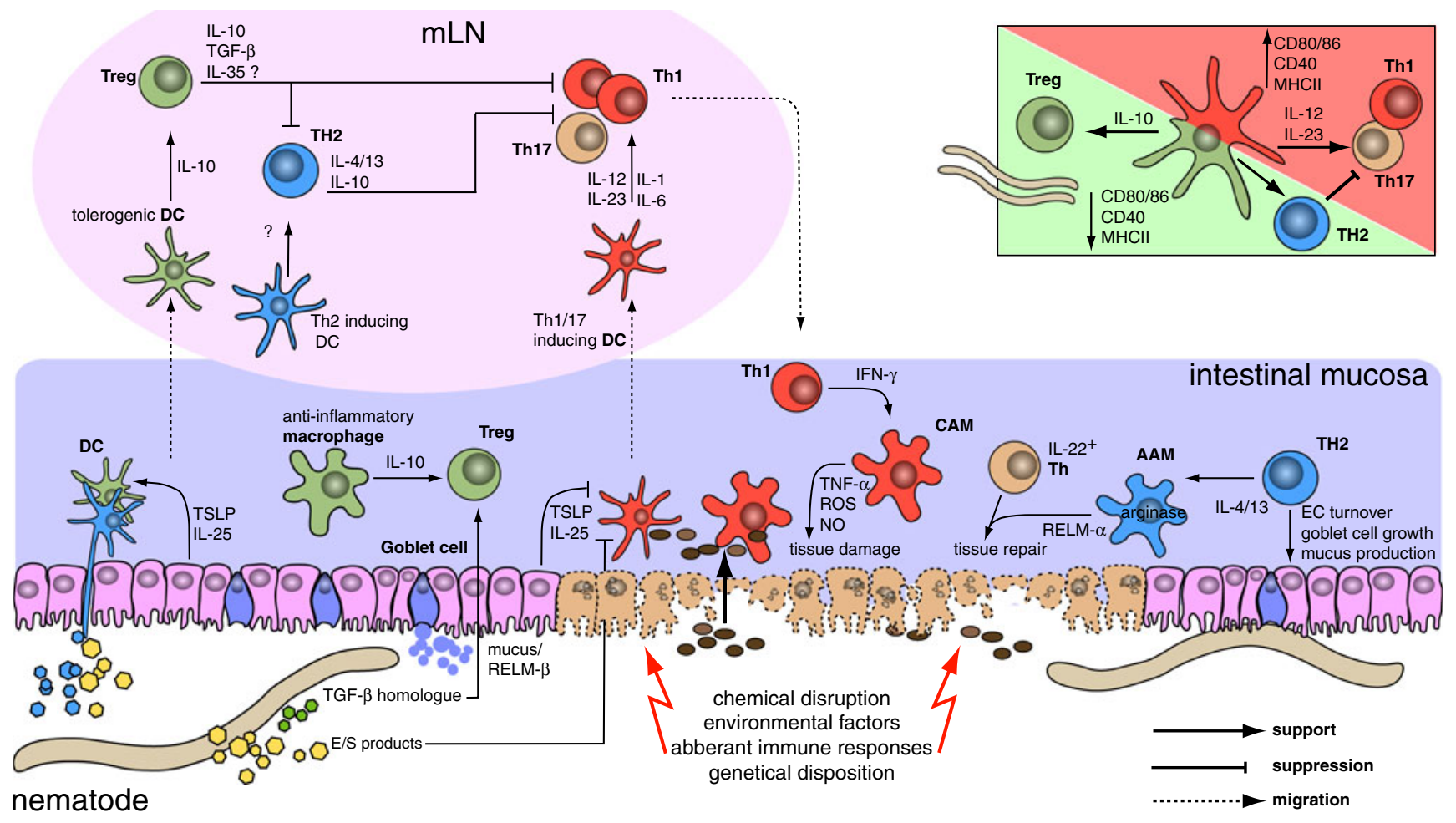

Fig. 1 A schematic overview of mechanisms suppressive to IBD conducted by intestinal nematodes. In susceptible individuals, environmental factors or genetic predisposition provokes damage to the epithelial barrier of the intestine and lead to a mucosal immune response, with macrophages producing high amounts of proinflammatory cytokines (TNF- $\alpha$ and others) and tissue-destructive effector molecules (NO, ROS). The lost integrity of the epithelial cell barrier and insufficient mucus layer facilitate bacterial translocation to subepithelial regions. DCs are activated after recognition of bacterial components and migrate to the gut-draining $\mathrm{mLN}$, where they prime naïve $\mathrm{T}$ cells and produce IL-12/23, leading to $\mathrm{CD}^{+} \mathrm{T}$ cell differentiation into Th1 and Th17 cells. These migrate to the intestine and perpetuate the inflammatory response, e.g., via IFN- $\gamma$ production which supports the activation of macrophages. On the contrary, DC activated via molecules released from nematodes will prime $\mathrm{Th} 2$ cells producing IL-4/-13. Tissue-derived cytokines like TSLP and IL-25 support the development of the Th2 response and suppress proinflammatory responses by DC and macrophages. The Th2 response counterbalances the activation and outgrowth on the opposing Th populations. IL-4/13 leads to the development of macrophages with an alternatively activated phenotype (AAM) expressing factors like arginase and RELM- $\alpha$ needed for wound repair. IL-4/13 also leads to an increased turnover of epithelial cells, hyperplasia of goblet cells, and increased mucus production. IL-22-producing Th cells may increase epithelial integrity. ES products from the nematodes directly modulate DC, suppressing their expression of MHCII, costimulatory molecules, and production of Th1- and Th17-supportive cytokines (see inlay). Certain nematode species directly favor the induction of Foxp $3^{+}$regulatory $\mathrm{T}$ cells via secretion of a mimic to TGF- $\beta$. DCs with a tolerogenic phenotype (e.g., production of IL-10) accumulate in mLN and support the production of IL-10 by $\mathrm{T}$ cells and the outgrowth of Treg populations. Tregs limit the activation and effector function of Th1 and Th17 as well as Th2 cells. AAM alternatively activated macrophage, $C A M$ classically activated macrophage, $D C$ dendritic cell, $E C$ epithelial cell, $E / S$ excretory/secretory components, $I F N-\gamma$ interferon- $\gamma, I L$ interleukin, $m L N$ gut-draining mesenteric lymph nodes, $N O$ nitric oxide, $R E L M-\alpha$ resistin-like molecule- $\alpha$, $R O S$ reactive oxygen species, TGF- $\beta$ transforming growth factor- $\beta$, Th helper T cell, $T N F-\alpha$ tumor necrosis factor- $\alpha$, Treg regulatory $\mathrm{T}$ cell, TSLP thymic stromal lymphopoietin 
1997; Metwali et al. 2006) as well as in human patients with long-lasting or recurring infections (Doetze et al. 2000; Fujiwara et al. 2009). The latter is seen as a consequence of limited activation by innate cells and increased numbers and activation of regulatory $\mathrm{T}$ cell (Treg) subsets, such as forkhead box P3 (Foxp $3^{+}$) expressing natural Tregs and induced Treg populations specialized for the expression of the anti-inflammatory cytokines transforming growth factor beta (TGF- $\beta$ ) (Th3 cells) and IL-10 (Tr1 cells) (Chaudhry et al. 2011; Doetze et al. 2000; Metenou et al. 2010). The understanding of how nematodes afflict the different immune cells of their hosts may help to specifically interfere with inflammatory disorders such as IBD.

The largest body of evidence for a preventive and curative effect of nematodes on gastrointestinal inflammation comes from commonly used murine colitis and nematode infections models (see Box 1, Tables 1 and 2 ). In the following section, we will focus on how nematode infections or nematode components modulate the multiple layers of immune responses and how this is connected to the control of inflammatory disorders of the gut.
Skewing the system: Th2-related protection against IBD

A highly conserved feature of nematode infections is the polarization towards a $\mathrm{Th} 2$ response and counter-regulation of Th1 responses (see Fig. 1). Thus, many studies have aimed to dissect how the nematode-induced Th2 response antagonizes pathological Th1 and Th17 responses in murine models of colitis.

Infections with Heligmosomoides polygyrus have potent protective effects and suppress inflammation in several models of IBD (see Table 2). Amelioration of trinitrobenzenesulfonic acid (TNBS)-induced or piroxicam-triggered colitis in IL-10 $10^{-/-}$mice (see Box 1) by prior infection with $H$. polygyrus coincided with increased colonic levels of Th2 cytokines, while local IL-12, IFN- $\gamma$, and TNF- $\alpha$ were conversely suppressed, suggesting that the preventive effect was largely due to the nematode-induced Th2 response counterbalancing Th1-driven tissue damage (Elliott et al. 2004; Setiawan et al. 2007; Sutton et al. 2008). Suppression of Th17-driven colitis by H. polygyrus in the IL10 $0^{-/-}$model has been linked to IL-4, a key Th2 cytokine. In vitro blockade of IL-4 restored the IL-17A production by T cells

Box 1: Mouse colitis models studied for nematode immunomodulation

\section{DNBS/TNBS model}

Induction: Immunological mediated model induced by the haptens di- or trinitrobenzene sulfonic acid (DNBS, TNBS) and the intestinal microbiota. Intrarectal application of chemicals in ethanol leads to disruption of epithelial layer (Scheiffele and Fuss 2002). Initiator of inflammatory response: IL-12/23 production by DC and macrophages, TNF- $\alpha /$ IL-1 $\beta / \mathrm{IL}-6 / \mathrm{IL}-18$ from macrophages (Guan et al. 2011; Neurath et al. 2000; Scheiffele and Fuss 2002). Dependent on adaptive immunity: Th1/17 cells drive the colitic response. Not working in T cell deficient mice (Scheiffele and Fuss 2002; Guan et al. 2011). Interference with inflammation: Blockade of IL-12/23 TNF- $\alpha$ (Neurath et al. 2000, Guan, 2011 \#124) Relevance to human IBD: Transmural inflammatory lesions share similarity with CD. Long lasting (about 8-12 weeks in susceptible mice). Responds to current treatments of IBD (sulfasalazine, gluocorticoids, cyclosporine, anti-TNF- $\alpha$ antibodies).

\section{DSS model}

Induction: feeding of dextran sodium sulphate (DSS) in drinking water leads to disruption of colonic mucosals barrier. DSS is directly toxic to epithelial cells and allows translocation of intestinal bacteria driving the pro-inflammatory response. Does not work in germ-free mice. Initiator of inflammatory response: macrophages sensing intestinal bacteria (Dieleman et al. 1994). Dependent on adaptive immunity: Macrophage-driven inflammation also detected in $\mathrm{T}$ cell deficient mice. Repetitive cycles of DSS application lead to exacerbated inflammation driven by Th1, Th17 and Th2 cells (Hall et al. 2011). Interference with inflammation: Removal of microbiota by antibiotic treatment; blockade of IL-12/23, TNF- $\alpha$. Relevance to human IBD: Early recruitment of DC, macrophages and neutrophils reflects findings in human IBD patients (Hall et al. 2011). Repetitive DSS mimic relapse and remission phases.

\section{IL-10-/- Model}

Induction: develops spontaneously in $\mathrm{IL}-10^{-/-}$mice or after transfer of IL-10 ${ }^{-/-} \mathrm{T}$ cells into RAG-/- mice deficient in mature $\mathrm{T}$ cells. Piroxicam treatment needed for synchronized colitic response. Does not work in germ-free mice (Blum et al. 2004; Kuhn et al. 1993). Initiator of inflammatory response: increased IL-12/23 production in response to bacterial stimuli due to increased mucosal permeability and lack of regulatory IL-10 circuits. Overt activation of Th1/17 effector cells liberated from (Tr1/Treg?) regulation (Elliott et al. 2004). Dependent on adaptive immunity: Unregulated pro-inflammatory $\mathrm{T}$ effector responses is responsible for colitis development. Interference with inflammation: removal of microbiota by antibiotic treatment; blockade of IL-12; co-transfer of Treg. Relevance to human IBD: Model for transmural inflammation as also seen in CD patients. Reflects unregulated $\mathrm{T}$ cell responses due to a defect in regulatory circuits that may be involved in genetically predisposed IBD patients. 


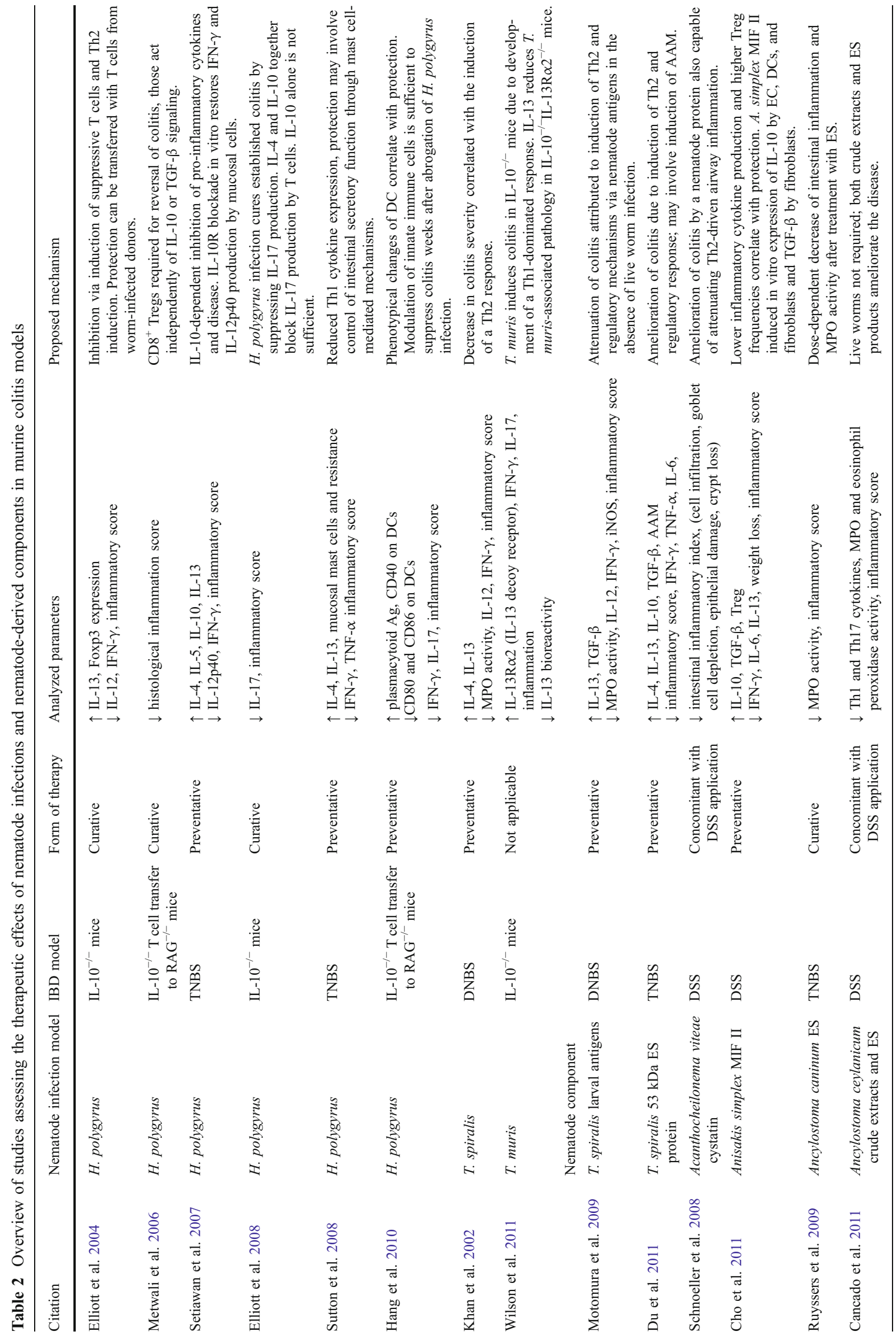


from nematode-infected IL $10^{-/-}$mice. Conversely, addition of IL-4 (and more so the combination of IL-4 and IL-10) blocked IL-17A secretion by $\mathrm{T}$ cells from colitic IL-10 ${ }^{-/-}$ mice, showing that nematode-driven Th2 effector cytokines effectively suppress pro-inflammatory responses (Elliott et al. 2008). Importantly, H. polygyrus infection not only prevented development of colitis when given to mice before administration of the colitis trigger piroxicam, but was also able to control established colitis in IL-10 $0^{-/}$mice (Elliott et al. 2008).

A recent publication specifically addressed the role of IL-13, a Th2 cytokine sharing many features with IL-4, and IL-13R $\alpha 2$, the soluble IL-13 decoy receptor limiting the levels of bioactive IL-13 in the body, in Trichuris muris infection (Wilson et al. 2011). Infections with T. muris lead to a pathological response resembling colitis in $\mathrm{IL}-10^{-/-}$ mice, which were found to express high levels of IL-13R $\alpha 2$ following $T$. muris infection or piroxicam treatment. Using IL-10/IL-13R $\alpha 2$ double knockout mice, the authors found that in the absence of the decoy receptor a subsequent increase in IL-13 bioactivity protected against IFN- $\gamma$ and IL-17A-mediated colitis. An increase in IL-13 and decreased IFN- $\gamma$ were also reported in Trichinella spiralismediated amelioration of dinitrobenzene sulfonic acid (DNBS) colitis (Khan et al. 2002). Taken together, these data suggest that the initial strong induction of Th2 responses by nematode infections counterbalances the development of colitogenic Th1 and Th17 responses and show that even fully developed colitis may be controlled by nematode treatment.

The first line of modulation: intestinal epithelial cells and tissue-derived cytokines

The integrity of the epithelial layer is of pivotal importance for the prevention of inappropriate inflammatory responses against the commensal gut microbiota (Saenz et al. 2008). Intestinal nematode infections lead to a rapid innate response that results in a bias towards the induction of an adaptive Th2 response in order to expel developing larvae or adults. Recent work has shown how the epithelialderived cytokines thymic stromal lymphopoietin (TSLP), IL-25, and IL-33 influence innate and adaptive responses at mucosal sites and how they are involved in promoting Th2 responses to intestinal nematode infections (Saenz et al. 2008; Humphreys et al. 2008; Price et al. 2010; Taylor et al. 2009). TSLP and IL-25 have been shown to turn off the expression of IL-12/23 p40 by DCs and thus impair their ability to drive Th1 responses (Massacand et al. 2009; Taylor et al. 2009). In the absence of TSLP, T. muris infection led to severe gut pathology coinciding with increased Th1 and Th17 responses (Taylor et al. 2009). Importantly, the same study showed that mice deficient in
TSLP develop a more severe pathology in response to dextran sodium sulfate (DSS; see Box 1) treatment in the chemically induced colitis model. Biopsies from patients with active CD showed a lack of TSLP expression compared to healthy controls (Rimoldi et al. 2005). Treatment of colonic macrophages from IBD patients with the tissue-derived cytokine IL-25 restrained their synthesis of IL-12/23 and, similar to TSLP, patients with active UC or CD produced less IL-25 than healthy controls. Furthermore, application of IL-25 ameliorated experimental colitis in mice (Caruso et al. 2009). IL-33, on the other hand, is discussed as a factor driving gut inflammation, especially in Th2-related UC (Seidelin et al. 2011) and was shown to exacerbate DSS-induced experimental colitis (Imaeda et al. 2011).

Another innate effector molecule produced by the intestinal epithelium, namely goblet cells, in response to worm infections is resistin-like molecule beta (RELM- $\beta$ ). RELM- $\beta$ is induced by IL- $4 /-13$ produced by early innate sources and Th2 cells and is directly involved in host defense against intestinal nematodes by binding to the chemosensory apparatus of the worms (Artis et al. 2004; Herbert et al. 2009). Furthermore, it increases mucin secretion by goblet cells and ameliorates TNBS colitis in mice by strengthening the mucus layer needed for gut barrier function and immune homeostasis (Hogan et al. 2006; Krimi et al. 2008).

The early induction of TSLP and IL-25 by nematode infections permits the development of adequate mucosal $\mathrm{Th} 2$ responses directed against the parasite while suppressing pathogenic Th1 and Th17 responses. Thus, the increased expression of tissue-derived factors like TSLP, IL-25, and RELM- $\beta$ induced by nematodes seems integral to a protective role of these parasites in colitis models. While many studies focus on these tissue-derived cytokines as targets in modulating Th2-related atopic disorders, nematode infection models may reveal how these early players in mucosal immune responses might also be targets for suppressing Th1- and Th17-related gut inflammation.

DC as nematode modulation targets

Dendritic cells (DCs) are the most potent antigenpresenting cells and critical inducers of adaptive immunity. They play a decisive role in directing the differentiation of distinct $\mathrm{Th}$ cell as well as $\mathrm{T}$ regulatory cell subsets in response to pathogens (MacDonald and Maizels 2008). In active lesions of IBD patients, increased numbers of activated DCs are detectable, expressing toll-like receptors (TLRs) essential for the recognition of microbial pathogens and commensal bacteria as well as co-stimulatory molecules needed for the activation of T cells. As to be expected, they also produce high levels of inflammatory cytokines, 
including IL-12/23p40 (Niess 2008). Given the fact that the production of IL-12/23 by gut-associated DCs is essentially involved in the induction of colitogenic Th1 and Th17 responses, it is interesting to note that many in vitro and in vivo studies show that nematode infections as well as nematode products efficiently shut down the ability of DCs to produce these pro-inflammatory factors.

Treatment of DCs with ES products of parasitic nematodes selectively suppresses their production of IL-12 in response to TLR ligation by bacterial components and/or the expression of co-stimulatory molecules (such as CD80/ 86 and CD40) and antigen presentation molecule MHCII (Balic et al. 2009; Li et al. 2011; Segura et al. 2007). Similarly, blood monocyte-derived DCs from patients infected with the hookworm Necator americanus were impaired in their ability to induce $\mathrm{T}$ cell activation and proliferation (Fujiwara et al. 2009). For T. muris, it was shown that infection led to a rapid increase of immature DCs in the lamina propria of the large intestine (Cruickshank et al. 2009). The colonic DCs were shown to extend dendrites between adjacent epithelial cells into the gut lumen (Cruickshank et al. 2009). Therefore, it is conceivable that DCs are a direct target of immunomodulatory components secreted by $T$. muris and other intestinal nematodes and may be modulated directly in the intestine.

Divergent DC populations with pro-tolerogenic properties have been characterized, like mucosal $\mathrm{RALDH}^{+} \mathrm{CD} 103^{+} \mathrm{DCs}$ or lymphoid $\mathrm{CD} 205^{+}$DCs driving the induction of regulatory $\mathrm{T}$ cells and plasmacytoid DCs inducing IL-10 production by T cells (Coombes and Maloy 2007; Pulendran et al. 2010; Yamazaki et al. 2008). This raised the question whether nematodes might support such pro-tolerogenic DC populations and thus prevent the development of pathological $\mathrm{T}$ cell responses in the gut. A recent study provides first evidence for prevention of colitis by efficient modulation of DCs and other innate immune cells by an intestinal nematode. In the IL- $10^{-/-} \mathrm{T}$ cell transfer colitis model, a transient infection with $H$. polygyrus weeks before the IL- $10^{-/} \mathrm{T}$ cell transfer led to protection from colitis by suppressing the subsequent generation of colitogenic Th1 and Th17 effector cells. Changes in the composition of lamina propria-derived DCs populations were related to the inhibition of colitis as DCs showed decreased expression of co-stimulatory molecules and IL-12/23 p40 and contained higher frequencies of plasmacytoid-like DCs known to exert a regulatory function in disease models (Hang et al. 2010).

A refined analysis of intestinal nematode-induced changes in DC populations has been carried out in the group of Rick Maizels using H. polygyrus and Nippostrongylus brasiliensis as models for chronic and acute nematode infections. In both infections, the number of DCs expressing high levels of co-stimulatory molecules dropped dramatically in gut-draining mesenteric lymph nodes $(\mathrm{mLN})$, a finding even more prevalent during chronic $H$. polygyrus infection (Balic et al. 2009). This coincided with an increased Th2-inducing and restrained Th1-priming capacity of mLN DCs (Balic et al. 2009). In a subsequent study, an increased frequency of DCs with a pro-tolerogenic phenotype distinct from previously described CD205 ${ }^{+}$, $\mathrm{CD}_{103^{+}}$, and plasmacytoid DCs was detected in the $\mathrm{mLN}$ of H. polygyrus-infected mice (Smith et al. 2011). These DCs responded poorly to TLR ligands and had a low efficiency in driving Th1 and Th17 differentiation, but were superior in driving Th2 responses and de novo induction of Foxp $3^{+}$Tregs (Smith et al. 2011).

It is thus conceivable that the reduction in propathogenic DCs and the increase of pro-tolerogenic DCs found during nematode infections are largely contributing to the profound anti-inflammatory effects of these parasites seen in IBD models and clinical trials. The fact that intestinal DCs sample antigen directly from the gut lumen (Niess et al. 2005) makes them a potential target for direct modulation via ES products of nematodes. Thus, it is also conceivable that immature DCs attracted to nematodeinfected intestinal sites are efficiently modulated by ES products of the parasites, either blocking their further maturation, inhibiting migration to lymphoid sites, or equipping them with pro-tolerogenic functions exerted after their arrival at sites of $\mathrm{T}$ cell priming.

It should also be noted that the mechanisms involved in immune modulation may vary between species of nematodes. For example, the suppression of IL-12/23 p40 expression by DCs is dependent on the tissue-derived cytokine TSLP in $T$. muris infection, while $H$. polygyrus and $N$. brasiliensis are able to bypass the need for TSLP, directly suppressing the expression of pro-inflammatory cytokines by DCs through ES components (Massacand et al. 2009). Therefore, for developing nematode-derived anti-colitic therapies, differences between immune response induced between nematode species must be considered.

\section{Nematode modulation of macrophages}

Intestinal macrophages are known for their contribution to IBD as effector cells driving pathology by release of the pro-inflammatory cytokines TNF- $\alpha$, IL-1 $\beta$, IL-6, IL-12, and IL-23, reactive oxygen species, and nitric oxide (Qualls et al. 2006; Bar-On et al. 2011). On the other hand, they are necessary for maintenance of intestinal homeostasis via induction of Treg differentiation (Denning et al. 2007). During nematode infections, macrophages acquire a special phenotype (named alternatively activated macrophages; AAMs) in response to the Th2 cytokines IL- 4 and -13 (Loke et al. 2007; Reece et al. 2008; Siracusa et al. 2008; Gordon 2003). They are characterized by the expression of 
arginase-1, RELM- $\alpha$, and YM-1, effector molecules involved in wound healing and protection against nematodes (Kreider et al. 2007). Importantly, AAMs express low levels of pro-inflammatory cytokines.

While not yet studied directly in nematode infections, AAMs may play a role in amelioration of gastrointestinal inflammation as AAMs are found in higher amounts in human patients with inactive CD compared to those with active disease (Hunter et al. 2010). This finding along with the observation that nematode infections induce AAMs with wound healing and tissue remodeling properties, as well as potential T cell suppressive capabilities, (Mylonas et al. 2009; Siracusa et al. 2008) prompts the question whether AAMs might be involved in colitis prevention in nematode infection models.

Recent in vivo and in vitro data support this view: AAMs isolated ex vivo have the potential to ameliorate DSS-induced colitis after transfer (Weisser et al. 2011), and AAMs elicited by in vivo application of the Th2-associated tissue-derived cytokine IL-25 conferred protection against TNBS-induced colitis in an IL-4-, IL-13-, and TGF- $\beta$ independent manner (Rizzo et al. 2011). Helminth-derived AAMs are also found to have anti-inflammatory effects and are involved in wound healing (Loke et al. 2007). In a murine wound healing model, AAMs elicited by the filarial nematode Brugia malayi were found to be recruited to the site of injury after sham surgery of the intestine (Loke et al. 2007). In models with intestinal barrier disruption, as in the DSS model of colitis, it is easy to speculate that wound healing by AAMs induced during nematode infection could participate in the protective effect observed. AAMs generated in vitro reduced colonic inflammation in DNBS-treated mice, and similarly, a protective, anti-colitic effect mediated by tapeworm infections was reverted when intestinal macrophages were depleted (Hunter et al. 2010). Interestingly, the same study showed that patients with active colitis had reduced numbers of AAMs in intestinal biopsies, while inactive $C D$ correlated with increased numbers of intestinal AAMs (Hunter et al. 2010). The observation that remission in $\mathrm{CD}$ patients is correlated with an accumulation of AAMs in the intestine coupled with the reported protective role of helminth-induced AAMs in murine models of colitis suggests that a better understanding of the role of AAMs may yield important information for the application of modulated macrophage subsets as therapy for intestinal inflammatory disorders.

Anti-inflammatory cytokines: nematodes supporting the production of IL-10 and TGF- $\beta$

IL-10 and TGF- $\beta$ are canonical regulatory cytokines which are produced by a multitude of innate and adaptive immune cells as well as epithelial cells. Both play a crucial role in maintaining immune homeostasis of the gut. They suppress the production of pro-inflammatory cytokines by innate cells and the development of Th1 cells (Doligalska et al. 2006; Elliott et al. 2008; Ince et al. 2009) while supporting and inducing regulatory $\mathrm{T}$ cell subsets (Coombes and Maloy 2007; Murai et al. 2009). Genetically modified mice with dysfunctional TGF- $\beta$ signaling (Fahlen et al. 2005; Gorelik and Flavell 2000) or lacking IL-10 expression (Asseman et al. 1999; Murai et al. 2009) succumb to severe colitis due to a dysregulated cytokine milieu with overt proinflammatory $\mathrm{T}$ cell activation. Tregs are one important source of both cytokines (Monteleone et al. 2008; Rubtsov et al. 2008), and IL-10 from intestinal macrophages has been shown to induce Foxp $3^{+}$Tregs in conjunction with retinoic acid and exogenous TGF- $\beta$ (Denning et al. 2007). Macrophage-derived IL-10 also maintains Foxp3 expression in gut Tregs in the inflamed intestine (Murai et al. 2009).

Nematode infections provoke the production of IL-10 and TGF- $\beta$ by T cells (indicative of a Treg phenoytpe, see next section) (Doetze et al. 2000; Finney et al. 2007; Rausch et al. 2008; Rausch et al. 2009; Satoguina et al. 2002; Schopf et al. 2005), and both cytokines restrain protective antiparasitic immune responses and immunopathology (Grainger et al. 2010; Specht et al. 2004). Thus, IL10 and TGF- $\beta$ are central mediators of nematode-induced protection against intestinal inflammation. H. polygyrus infection leads to an increased production of IL-10 by $\mathrm{CD}^{+} \mathrm{T}$ cells in the lamina propria of the lower intestine while decreasing levels of IFN- $\gamma$ and IL12/23 p40 (Setiawan et al. 2007). In the TNBS model, IL-10 was proposed to be essential for disease resolution by $H$. polygyrus because blockade of the IL-10R restored Th1 responses and reversed the protection against colitis (Setiawan et al. 2007). More recently, the importance of TGF- $\beta$ was shown in $H$. polygyrus-mediated suppression of intestinal inflammation (Ince et al. 2009). Control of Th1-driven colitis by $H$. polygyrus required intact TGF- $\beta$ signaling as mice with a defective form of TGF- $\beta$ RII showed no reduction in intestinal Th1 cytokine production and were not protected from colitis by $H$. polygyrus infection. Interestingly, this study indicated a link between TGF- $\beta$ and IL-10 expression as TGF- $\beta$ RII-defective mice lacked the increased intestinal IL-10 levels seen in $H$. polygyrus-infected wild-type mice. $H$. polygyrus also modulates the response of $\mathrm{T}$ cells to bacterial components in favor of an anti-inflammatory cytokine response. During infection, intestinal mucosal T cells were found to start expressing TLR-4, the receptor for bacterial lipopolysaccharide (LPS). Both $\mathrm{CD}^{+}$and $\mathrm{CD} 8^{+}$intestinal $\mathrm{T}$ cells from $H$. polygyrus-infected mice reacted with increased production of TGF- $\beta$ in response to LPS stimulation (Ince et al. 2006). This mechanism may 
help to maintain the mucosal integrity during intestinal worm infections and may be involved in suppressing colitic responses by nematodes.

There is increasing evidence that IL-10 from nematodemodulated DCs or T cells primed by these DCs might be important for nematode-mediated protection against colitis. DCs treated with ES products of $H$. polygyrus or the hookworm Ancylostoma caninum gained the ability to induce IL-10 in primed T cells (Cuellar et al. 2009; Segura et al. 2007). H. polygyrus infection led to an increase in IL10-expressing DCs in $\mathrm{mLN}$ that supported the induction of Tregs and IL-10 production by T cells (Balic et al. 2009; Li et al. 2011).

Resident gut macrophages also serve as a source for IL10 and TGF- $\beta$ in the intestine (Gordon 2003; Murai et al. 2009), and intestinal macrophages can confer protection from $\mathrm{T}$ cell transfer colitis in an IL-10-dependent manner (Murai et al. 2009). It is thus tempting to speculate that nematodes might support the inherent competence for IL-10 production in resident intestinal macrophages and, at the same time, prevent damage resulting from the release of high levels of inflammatory mediators by monocytes/ macrophages migrating to the gut tissue during onset or relapse of IBD. It remains to be elucidated whether this might be a mechanism centrally involved in the nematodemediated blockade of colitis in diverse gut inflammation models.

Treg induction and activation by nematodes

Regulatory $\mathrm{T}$ cells (Tregs) are essential for the control of immune disorders, and their role in preventing spontaneous or induced gut inflammation has been extensively studied (Campbell and Koch 2011; Izcue et al. 2009). Mice lacking the Treg-associated lineage transcription factor Foxp3 are prone to develop fatal colitis due to a dysregulated cytokine milieu with overt pro-inflammatory $\mathrm{T}$ cell activation. The production of TGF- $\beta$ and IL-10 by Tregs suppresses inflammation driven by effector $\mathrm{T}$ cells and innate cells (Chaudhry et al. 2011; Liu et al. 2006), and both cytokines are important for Treg maintenance in what appears to be a positive feedback loop (Murai et al. 2009; Fantini et al. 2004; Mucida et al. 2007).

Increased frequencies of Tregs are detected in nematodeinfected mice (D'Elia et al. 2009; Finney et al. 2007; Grainger et al. 2010; McSorley et al. 2008; Rausch et al. 2008) and humans (Babu et al. 2006; Matera et al. 2008; Metenou et al. 2010; Montes et al. 2009). Our group, as well as others, has shown that $H$. polygyrus-infected mice have higher frequencies of $\mathrm{CD}^{+}$Tregs and that they are stronger suppressors than Tregs from naïve controls (Finney et al. 2007; Rausch et al. 2008; Rausch et al. 2009). Infection-derived Tregs had an increased expression of the $\alpha_{\mathrm{E}}(\mathrm{CD} 103) \beta_{7}$ integrin linked to an activated effector/ memory phenoytpe of Foxp $3^{+}$Tregs (Huehn et al. 2004). CD103 binds to E-cadherin expressed on epithelial cells, possibly enabling prolonged retention of these Tregs in the intestine (Cepek et al. 1994). Most importantly, the depletion of Tregs during infections with $H$. polygyrus and T. muris increased intestinal pathology (D'Elia et al. 2009; Rausch et al. 2009). Thus, regulatory $\mathrm{T}$ cell populations are one focus in nematode protection against gut inflammation.

$\mathrm{CD}^{+} \mathrm{T}$ cells isolated from the intestines of $H$. polygyrus-infected mice efficiently blocked IFN- $\gamma$ production of $\mathrm{T}$ cells derived from worm-free mice. Although data on their Foxp3 expression are lacking, this shows the induction of a regulatory phenoytpe in gut-derived $\mathrm{CD} 4^{+}$ cells during $H$. polygyrus infection. The gut-derived $\mathrm{CD} 4^{+}$ $\mathrm{T}$ cells produced large amounts of IL-10, coinciding with the blockade of TNBS colitis in $H$. polygyrus-infected mice. Blockade of IL-10 in vitro restored the suppressed IFN- $\gamma$ and IL-12/23 p40 production by lamina propria cells derived from $H$. polygyrus-infected donors. In vivo, IL-10 blockade worsened TNBS colitis in H. polygyrusinfected mice (Setiawan et al. 2007). An earlier study linked an increased Foxp3 expression in mLN cells of $H$. polygyrus-infected mice to the protection from colitis achieved by $\mathrm{T}$ cell transfer from infected to naive IL-10 $0^{-/}$ mice (Elliott et al. 2004). As transfer of IL- $10^{-/-} \mathrm{T}$ cells from $H$. polygyrus-infected donors blocked colitis in IL$10^{-/-}$recipients, the suppression of intestinal inflammation exerted by regulatory $\mathrm{T}$ cells activated by the worm infection is not solely based on IL-10 production. Interestingly, $H$. polygyrus also induces a $\mathrm{CD}^{+}$Treg population. $\mathrm{CD}^{+} \mathrm{T}$ cells isolated from the intestines of $H$. polygyrus-infected mice were able to largely inhibit proliferation of spleen cells from naïve mice in vitro, whereas $\mathrm{T}$ cells isolated from naïve mice showed very little effect. The $H$. polygyrus-driven regulatory activity in $\mathrm{CD} 8^{+}$intestinal $\mathrm{T}$ cells was independent of IL-10 and TGF- $\beta$, but worked in a contact-dependent manner (Metwali et al. 2006).

Recently, it was shown that ES products of $H$. polygyrus (and the related nematode Teladorsagia circumcincta) contain a functional mimic of TGF- $\beta$ able to induce Foxp3 expression in $\mathrm{CD}^{+} \mathrm{T}$ cells in vitro, thus potentially enhancing the suppressive natural Treg pool (Grainger et al. 2010). Importantly, the study also shows that $H$. polygyrus infection greatly enhanced the induction of Tregs specific for an irrelevant antigen in a model of oral tolerance induction. This shows that nematodes are able to induce Tregs not specific for parasite antigen and suggests that the induced Tregs may be of essential benefit in regulating dyregulated immunity or bowel inflammation driven by the microbiota. 
Taken together, it is clear that Tregs exposed to nematodes or nematode antigens are highly activated and may efficiently control immune responses. However, more work is needed to elucidate the pathways involved in Treg activity in intestinal nematode infections and their contribution to the amelioration of colitis. In future studies, the Treg populations essentially involved in amelioration of colitis by nematode infections should be better characterized. It is not yet clear whether natural $\mathrm{CD} 4^{+} \mathrm{Foxp} 3^{+} \mathrm{T}$ cells, induced TGF- $\beta^{+}$Th3, or IL- $10^{+} \operatorname{Tr} 1$ cells are predominantly involved in suppressing colitis. The recently described IL-35 producing induced Tregs found expanded in T. muris infection (Collison et al. 2010) should also be evaluated as possible anti-colitic players supported by worm infections.

\section{Clinical trials and case studies}

The experimental work in mouse models of colitis showed that nematodes have potent immunomodulatory effects and lead to the induction of regulatory pathways. This generated interest in adapting experimental helminth application as a therapy in human disease. Clinical trials with IBD patients treated with ova from the pig specific whipworm Trichuris suis (see Table 3) showed an amelioration of symptoms with a decreased disease activity in nematodetreated patients (Summers et al. 2003; Summers et al. 2005). In the first T. suis study, small groups of ulcerative colitis and Crohn's disease patients were given 2,500 T. suis ova orally, and no adverse effects were observed (Summers et al. 2003). In three of four CD patients, remission was achieved within 12 weeks of $T$. suis ova ingestion. Since $T$. suis is not adjusted to the human host, it is considered as incapable of maintaining a chronic infection, and it was proposed that $T$. suis ova should be ingested every 3 weeks after the initial dose in order to maintain remission of colitis. In the second T. suis trial (Summers et al. 2005), 29 $\mathrm{CD}$ patients were treated with this regimen, and almost $80 \%$ responded, with $73 \%$ entering remission within 24 weeks of treatment. As immune reactivity was not measured in blood or tissue biopsies from the patients, the mechanism of $T$. suis-mediated amelioration of $\mathrm{CD} / \mathrm{UC}$ remains elusive.

A recent case study of an UC patient refractory to standard treatment investigated the effects of Trichuris trichiura, a close relative of $T$. suis infective for humans. The patient entered complete remission for 3 years after ingestion of two doses of embryonated T. trichiura eggs, leading to chronic infection (Broadhurst et al. 2010). Following a relapse phase, the patient ingested a third dose of T. trichiura, again leading to improvement of histopathological findings. The remission after reinfection correlated with an increase of colonic and systemic Th2- and IL-22-

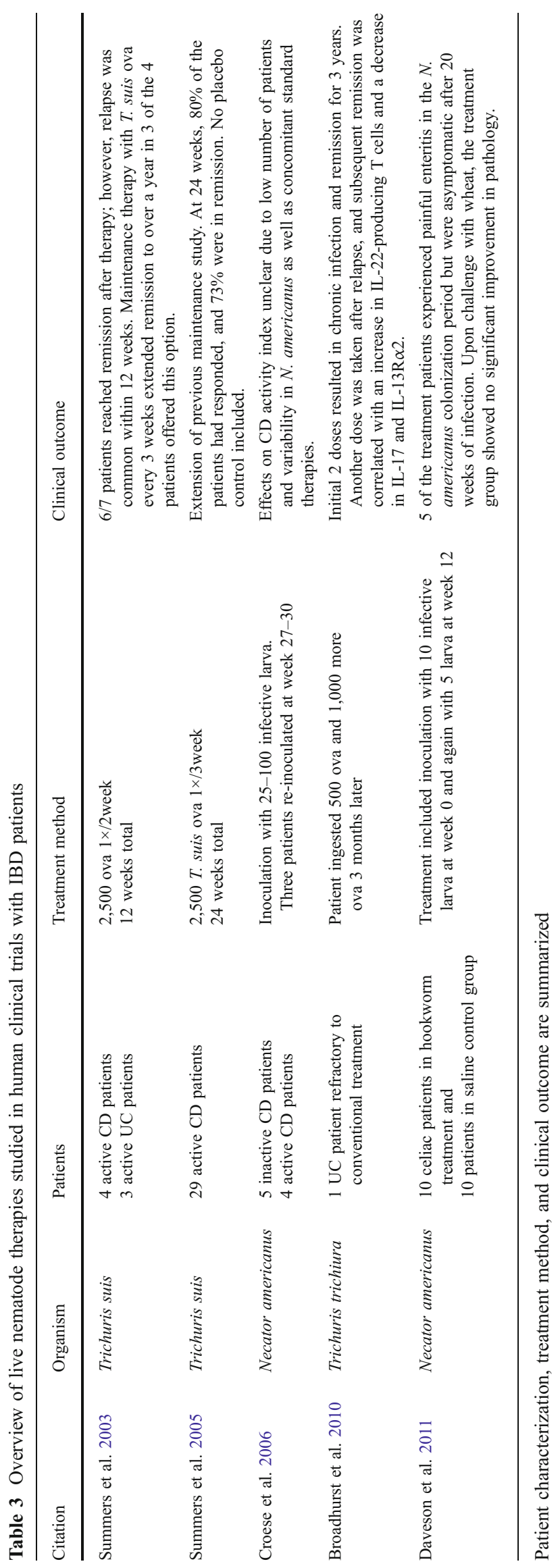


producing Th cells, while frequencies of Th cells producing the pro-colitic cytokines IFN- $\gamma$, IL-17, and TNF- $\alpha$ remained largely unchanged (Broadhurst et al. 2010). IL22, a cytokine produced by Th17 among other cells, is known to support mucosal integrity by promoting wound healing, increasing mucus production by goblet cells, and proliferation of epithelial cells, thus increasing mucosal barrier function (Eyerich et al. 2010). It was hypothesized that the infection with $T$. trichiura led to the induction of Th2- and IL-22-producing cells (in order to expel the parasite infection) and that these effector cells synergize in reducing intestinal pathology as a bystander effect by increasing the mucosal integrity. Studies with more patients are clearly needed to verify this hypothesis.

\section{Refining and advancing nematode derived therapies}

While infection with certain species of helminthes may result in a beneficial suppression of dysregulated inflammation, it is important to consider the consequences of administering helminths to patients as they are pathogens with the potential to induce adverse effects. High-dose infections with hookworms (e.g., N. americanus) or the whipworm $T$. trichiura can lead to a dysentery condition, malnutrition, and anemia as well as decreased cognitive function and retarded development in school-age children (Bager et al. 2011; Croese et al. 2006; Stephenson et al. 2000). The Th2 and regulatory immune response elicited in nematode infections may also have negative consequences in terms of responses to bystander infections. Nematodes blocking inflammatory Th1 response have been shown to enhance the susceptibility of the host to gastrointestinal bacterial pathogens (Chen et al. 2005; Chen et al. 2006), tuberculosis (Potian et al. 2011), and plasmodium infection (Tetsutani et al. 2009). Therefore, infections with live nematodes adapted to humans are not the ideal option for treatment of IBD.

As depicted above, eggs from T. suis-a species maladjusted to the human host-have been used in clinical trials to treat IBD as a way to circumvent the deleterious effects of worm infection. While it is thought that T. suis ova are unable to mature into breeding adults in the human, a case study of a 16-year-old boy treated with $T$. suis ova for IBD found not only an adult male worm in the intestinal lumen of the boy but also suggested that the gastrointestinal inflammation present was due to a $T$. suis-induced Th2 inflammatory response (Kradin et al. 2006). Likewise, in a recent double-blind placebo trial, a significant increase in the number of patients reporting gastrointestinal symptoms, such as diarrhea and abdominal pain, was observed in $T$. suis ova-treated patients compared to the placeboadministered control group (Bager et al. 2011). The human specific hookworm $N$. americanus has also been administered in $\mathrm{CD}$ patients in an attempt to ameliorate disease activity (Croese et al. 2006). While no significant decrease in $\mathrm{CD}$ activity index was observed for 17 weeks, enteropathy was noted both in $N$. americanus-treated CD patients and in human $N$. americanus reservoir donors (Croese et al. 2006). More recently, in a double-blind placebo control study, infective $N$. americanus larvae were given to celiac disease patients. An increase in nausea, bloating, and itchiness at infective sites was observed in early colonization periods lasting up to 16 weeks (Daveson et al. 2011). At 20 weeks postinfection, patients began a 5-day gluten challenge that resulted in no significant difference between the placebo control and treatment groups in parameters such as pain, vomiting, diarrhea, bloating, headache, lethargy, and overall well-being, in response to gluten (Daveson et al. 2011).

The potential for nematode infection to induce pathology and increase susceptibility to secondary infections, as well as the lack of long-term studies regarding these therapies, must be considered when evaluating nematode therapy. Likewise, the potential psychological effects of live worm treatment in patients living in a developed culture where hygiene may be correlated with status has to our knowledge never been studied. For these reasons, it would be beneficial to develop treatments that utilize nematode immune modulation while avoiding the induction of live nematode infections. One potential method of bypassing live worm infection, while still obtaining the positive effects of nematode immune modulation, is to uncover the specific compounds produced by these parasites and reveal the manner in which they act to downregulate inflammation in the gut. As reasoned above, ES products from nematodes and other helminths are promising candidates for the development of anti-inflammatory drugs.

To date, there are limited examples of studies examining nematode-derived immune-modulating components in colitis models. One component is a filarial nematode-derived cystatin that we previously reported to have ameliorative effects in a DSS model when administered intraperitoneally (Schonemeyer et al. 2001). Cystatins are ubiquitous cysteine protease inhibitors involved in numerous processes from catabolism to regulation of immune activation. However, it appears that parasitic nematode cystatins may have evolved a secondary role and are also capable of regulating the host immune system. Since the observation that Acanthocheilonema viteae cystatin is able to inhibit $\mathrm{T}$ cell proliferation (Hartmann et al. 1997), several other filarial cystatins, both native (Pfaff et al. 2002) and recombinant (Schierack et al. 2003; Schonemeyer et al. 2001), have been reported to suppress $T$ cell responses. Reduced antigen presentation and expression of costimulatory molecules by APCs has been observed when 
cells were exposed to filarial nematode cystatin (Manoury et al. 2001; Murray et al. 2005; Schonemeyer et al. 2001). Macrophages exposed to filarial cystatins were shown to increase the production of anti-inflammatory IL-10, as opposed to the increased IL-12 produced by macrophages exposed to Caenorhabditis elegans cystatins, supporting the theory of converging evolutionary development of cystatins in parasitic nematodes for establishment of chronic infection in the host (Schierack et al. 2003). Our group recently revealed the mechanism by which IL-10producing macrophages are induced by $A$. viteae cystatin (Klotz et al. 2011). We found that $A$. viteae cystatin is taken up by macrophages and activates the phosphorylation of mitogen-activated protein kinases (MAPK), resulting in the expression of IL-10 (Klotz et al. 2011). The regulation of this pathway involved the control of MAPK phopsphorylation by dual-specificity phosphatases, showing that the nematode cystatin exploits activation and deactivation pathways of MAPK to induce macrophages with an IL10-expressing phenotype (Klotz et al. 2011). We currently investigate the use of the nematode cystatin as therapeutic for IBD in more detail.

\section{Future perspectives for nematodes in IBD therapy}

While the research to date on nematode-derived immunomodulatory substances with potential benefits in IBD treatment is limited, it can be assumed that the overall anti-inflammatory effect of live worm infections may be due to more than one ES product or nematode component. Therefore, future therapies may benefit from synergistic effects of multiple nematode immunomodulatory products. It is also likely that various nematode components differ in their suppressive efficiency in individuals with different etiology or form of IBD. Genetic screening of individual IBD patients for known IBD-associated polymorphisms would be essential for developing patient-specific IBD treatment regimens, nematode derived and otherwise.

In conclusion, while there is strong evidence that nematode infections can downregulate intestinal inflammation, much more research on the responsible ES proteins or nematode components and the active mechanisms involved is required before safe treatment options can be clinically tested and marketed for routine use. Additionally, future IBD therapies developed from nematode products, as well as the currently marketed IBD therapies, might benefit from patient-specific genetic counseling to determine individual IBD phenotype and subsequent effective treatment regimen. These patient-specific therapies may involve nematode-derived treatments synergizing with the standard therapies.
Acknowledgments This study was supported by the German Research Foundation (DFG) through the Collaborative Research Centre 852 (grant no. SFB852/1) and by the Broad Medical Research Program (to S. H.). We thank Dr. M. R. Hepworth and Dr. S. Steinfelder for making valuable comments on the manuscript.

Conflict of interest The authors declare no financial or commercial conflict of interest.

Open Access This article is distributed under the terms of the Creative Commons Attribution Noncommercial License which permits any noncommercial use, distribution, and reproduction in any medium, provided the original author(s) and source are credited.

\section{References}

Anderson CA, Boucher G, Lees CW, Franke A, D'Amato M, Taylor KD, Lee JC, Goyette P, Imielinski M, Latiano A, Lagace C, Scott R, Amininejad L, Bumpstead S, Baidoo L, Baldassano RN, Barclay M, Bayless TM, Brand S, Buning C, Colombel JF, Denson LA, De Vos M, Dubinsky M, Edwards C, Ellinghaus D, Fehrmann RS, Floyd JA, Florin T, Franchimont D, Franke L, Georges M, Glas J, Glazer NL, Guthery SL, Haritunians T, Hayward NK, Hugot JP, Jobin G, Laukens D, Lawrance I, Lemann M, Levine A, Libioulle C, Louis E, McGovern DP, Milla M, Montgomery GW, Morley KI, Mowat C, Ng A, Newman W, Ophoff RA, Papi L, Palmieri O, Peyrin-Biroulet L, Panes J, Phillips A, Prescott NJ, Proctor DD, Roberts R, Russell R, Rutgeerts P, Sanderson J, Sans M, Schumm P, Seibold F, Sharma Y, Simms LA, Seielstad M, Steinhart AH, Targan SR, van den Berg LH, Vatn M, Verspaget $H$, Walters T, Wijmenga C, Wilson DC, Westra HJ, Xavier RJ, Zhao ZZ, Ponsioen CY, Andersen V, Torkvist L, Gazouli M, Anagnou NP, Karlsen TH, Kupcinskas L, Sventoraityte J, Mansfield JC, Kugathasan S, Silverberg MS, Halfvarson J, Rotter JI, Mathew CG, Griffiths AM, Gearry R, Ahmad T, Brant SR, Chamaillard M, Satsangi J, Cho JH, Schreiber S, Daly MJ, Barrett JC, Parkes M, Annese V, Hakonarson H, Radford-Smith G, Duerr RH, Vermeire S, Weersma RK, Rioux JD (2011) Meta-analysis identifies 29 additional ulcerative colitis risk loci, increasing the number of confirmed associations to 47. Nat Genet 43(3):246-252

Artis D, Wang ML, Keilbaugh SA, He W, Brenes M, Swain GP, Knight PA, Donaldson DD, Lazar MA, Miller HR, Schad GA, Scott P, Wu GD (2004) RELMbeta/FIZZ2 is a goblet cell-specific immuneeffector molecule in the gastrointestinal tract. Proc Natl Acad Sci U S A 101(37):13596-13600. doi:10.1073/pnas.0404034101

Asseman C, Mauze S, Leach MW, Coffman RL, Powrie F (1999) An essential role for interleukin 10 in the function of regulatory $\mathrm{T}$ cells that inhibit intestinal inflammation. J Exp Med 190(7):9951004

Babu S, Blauvelt CP, Kumaraswami V, Nutman TB (2006) Regulatory networks induced by live parasites impair both Th1 and Th2 pathways in patent lymphatic filariasis: implications for parasite persistence. J Immunol 176(5):3248-3256

Bager P, Kapel C, Roepstorff A, Thamsborg S, Arnved J, Ronborg S, Kristensen B, Poulsen LK, Wohlfahrt J, Melbye M (2011) Symptoms after ingestion of pig whipworm Trichuris suis eggs in a randomized placebo-controlled double-blind clinical trial. PLoS One 6(8):e22346

Balic A, Smith KA, Harcus Y, Maizels RM (2009) Dynamics of $\mathrm{CD} 11 \mathrm{c}( \pm)$ dendritic cell subsets in lymph nodes draining the site of intestinal nematode infection. Immunol Lett 127(1):68-75 
Bar-On L, Zigmond E, Jung S (2011) Management of gut inflammation through the manipulation of intestinal dendritic cells and macrophages? Semin Immunol 23(1):58-64

Blum AM, Metwali A, Elliott DE, Berg DJ, Weinstock JV (2004) CD4 $\pm \mathrm{T}$ cells from IL-10-deficient mice transfer susceptibility to NSAID-induced Rag colitis. Am J Physiol 287(2):G320-G325. doi:10.1152/ajpgi.00527.2003

Broadhurst MJ, Leung JM, Kashyap V, McCune JM, Mahadevan U, McKerrow JH, Loke P (2010) IL-22 \pm CD4 \pm T cells are associated with therapeutic Trichuris trichiura infection in an ulcerative colitis patient. Sci Trans Med 2(60):60ra88. doi:10.1126/scitranslmed.3001500

Campbell DJ, Koch MA (2011) Phenotypical and functional specialization of FOXP3 \pm regulatory T cells. Nat Rev 11(2):119-130

Cancado GG, Fiuza JA, de Paiva NC, Lemos LD, Ricci ND, Gazzinelli-Guimaraes PH, Martins VG, Bartholomeu DC, Negrao-Correa DA, Carneiro CM, Fujiwara RT (2011) Hookworm products ameliorate dextran sodium sulfate-induced colitis in BALB/c mice. Inflamm Bowel Dis. doi:10.1002/ibd.21629

Caruso R, Sarra M, Stolfi C, Rizzo A, Fina D, Fantini MC, Pallone F, MacDonald TT, Monteleone G (2009) Interleukin25 inhibits interleukin-12 production and Th1 cell-driven inflammation in the gut. Gastroenterology 136(7):2270-2279. doi:10.1053/j.gastro.2009.02.049

Cepek KL, Shaw SK, Parker CM, Russell GJ, Morrow JS, Rimm DL, Brenner MB (1994) Adhesion between epithelial cells and T lymphocytes mediated by E-cadherin and the alpha $\mathrm{E}$ beta 7 integrin. Nature 372(6502):190-193. doi:10.1038/372190a0

Chaudhry A, Samstein RM, Treuting P, Liang Y, Pils MC, Heinrich JM, Jack RS, Wunderlich FT, Bruning JC, Muller W, Rudensky AY (2011) Interleukin-10 signaling in regulatory $T$ cells is required for suppression of Th17 cell-mediated inflammation. Immunity 34(4):566-578

Chen CC, Louie S, McCormick B, Walker WA, Shi HN (2005) Concurrent infection with an intestinal helminth parasite impairs host resistance to enteric Citrobacter rodentium and enhances Citrobacter-induced colitis in mice. Infect Immun 73(9):54685481

Chen CC, Louie S, McCormick BA, Walker WA, Shi HN (2006) Helminth-primed dendritic cells alter the host response to enteric bacterial infection. J Immunol 176(1):472-483

Cho MK, Lee CH, Yu HS (2011) Amelioration of intestinal colitis by macrophage migration inhibitory factor isolated from intestinal parasites through toll-like receptor 2. Parasite Immunol 33 (5):265-275. doi:10.1111/j.1365-3024.2010.01276.x

Collison LW, Chaturvedi V, Henderson AL, Giacomin PR, Guy C, Bankoti J, Finkelstein D, Forbes K, Workman CJ, Brown SA, Rehg JE, Jones ML, Ni HT, Artis D, Turk MJ, Vignali DA (2010) IL-35mediated induction of a potent regulatory $\mathrm{T}$ cell population. Nat Immunol 11(12):1093-1101. doi:10.1038/ni.1952

Coombes JL, Maloy KJ (2007) Control of intestinal homeostasis by regulatory $\mathrm{T}$ cells and dendritic cells. Semin Immunol 19 (2):116-126

Croese J, O’Neil J, Masson J, Cooke S, Melrose W, Pritchard D, Speare R (2006) A proof of concept study establishing Necator americanus in Crohn's patients and reservoir donors. Gut 55(1):136-137

Cruickshank SM, Deschoolmeester ML, Svensson M, Howell G, Bazakou A, Logunova L, Little MC, English N, Mack M, Grencis RK, Else KJ, Carding SR (2009) Rapid dendritic cell mobilization to the large intestinal epithelium is associated with resistance to Trichuris muris infection. J Immunol 182(5):30553062

Cuellar C, Wu W, Mendez S (2009) The hookworm tissue inhibitor of metalloproteases (Ac-TMP-1) modifies dendritic cell function and induces generation of CD4 and CD8 suppressor T cells. PLoS Negl Trop Dis 3(5):e439
D'Elia R, Behnke JM, Bradley JE, Else KJ (2009) Regulatory T cells: a role in the control of helminth-driven intestinal pathology and worm survival. J Immunol 182(4):2340-2348

Daveson AJ, Jones DM, Gaze S, McSorley H, Clouston A, Pascoe A, Cooke S, Speare R, Macdonald GA, Anderson R, McCarthy JS, Loukas A, Croese J (2011) Effect of hookworm infection on wheat challenge in celiac disease - a randomised double-blinded placebo controlled trial. PLoS One 6(3):e17366

Denning TL, Wang YC, Patel SR, Williams IR, Pulendran B (2007) Lamina propria macrophages and dendritic cells differentially induce regulatory and interleukin 17-producing $\mathrm{T}$ cell responses. Nat Immunol 8(10):1086-1094

Dieleman LA, Ridwan BU, Tennyson GS, Beagley KW, Bucy RP, Elson CO (1994) Dextran sulfate sodium-induced colitis occurs in severe combined immunodeficient mice. Gastroenterology 107 (6): $1643-1652$

Doetze A, Satoguina J, Burchard G, Rau T, Loliger C, Fleischer B, Hoerauf A (2000) Antigen-specific cellular hyporesponsiveness in a chronic human helminth infection is mediated by $\mathrm{T}(\mathrm{h}) 3 / \mathrm{T}(\mathrm{r})$ 1-type cytokines IL-10 and transforming growth factor-beta but not by a T(h)1 to T(h)2 shift. Int Immunol 12(5):623-630

Doligalska M, Rzepecka J, Drela N, Donskow K, Gerwel-Wronka M (2006) The role of TGF-beta in mice infected with Heligmosomoides polygyrus. Parasite Immunol 28(8):387-395

Du L, Tang H, Ma Z, Xu J, Gao W, Chen J, Gan W, Zhang Z, Yu X, Zhou X, Hu X (2011) The protective effect of the recombinant 53-kDa protein of Trichinella spiralis on experimental colitis in mice. Dig Dis Sci 56(10):2810-2817

Duerr RH, Taylor KD, Brant SR, Rioux JD, Silverberg MS, Daly MJ, Steinhart AH, Abraham C, Regueiro M, Griffiths A, Dassopoulos T, Bitton A, Yang H, Targan S, Datta LW, Kistner EO, Schumm LP, Lee AT, Gregersen PK, Barmada MM, Rotter JI, Nicolae DL, Cho JH (2006) A genome-wide association study identifies IL23R as an inflammatory bowel disease gene. Science 314 (5804):1461-1463

Elliott DE, Urban JJ, Argo CK, Weinstock JV (2000) Does the failure to acquire helminthic parasites predispose to Crohn's disease? FASEB J 14(12):1848-1855

Elliott DE, Setiawan T, Metwali A, Blum A, Urban JF Jr, Weinstock JV (2004) Heligmosomoides polygyrus inhibits established colitis in IL-10-deficient mice. Eur J Immunol 34(10):2690-2698

Elliott DE, Metwali A, Leung J, Setiawan T, Blum AM, Ince MN, Bazzone LE, Stadecker MJ, Urban JF Jr, Weinstock JV (2008) Colonization with Heligmosomoides polygyrus suppresses mucosal IL-17 production. J Immunol 181(4):2414-2419

Eyerich S, Eyerich K, Cavani A, Schmidt-Weber C (2010) IL-17 and IL-22: siblings, not twins. Trends Immunol 31(9):354-361. doi:10.1016/j.it.2010.06.004

Fahlen L, Read S, Gorelik L, Hurst SD, Coffman RL, Flavell RA, Powrie F (2005) T cells that cannot respond to TGF-beta escape control by $\mathrm{CD} 4( \pm) \mathrm{CD} 25( \pm)$ regulatory T cells. J Exp Med 201 (5):737-746

Fantini MC, Becker C, Monteleone G, Pallone F, Galle PR, Neurath MF (2004) Cutting edge: TGF-beta induces a regulatory phenotype in CD4 \pm CD25- T cells through Foxp3 induction and down-regulation of Smad7. J Immunol 172(9):5149-5153

Finney CA, Taylor MD, Wilson MS, Maizels RM (2007) Expansion and activation of $\mathrm{CD} 4( \pm) \mathrm{CD} 25( \pm)$ regulatory $\mathrm{T}$ cells in Heligmosomoides polygyrus infection. Eur J Immunol 37(7):18741886

Franke A, McGovern DP, Barrett JC, Wang K, Radford-Smith GL, Ahmad T, Lees CW, Balschun T, Lee J, Roberts R, Anderson CA, Bis JC, Bumpstead S, Ellinghaus D, Festen EM, Georges M, Green T, Haritunians T, Jostins L, Latiano A, Mathew CG, Montgomery GW, Prescott NJ, Raychaudhuri S, Rotter JI, Schumm P, Sharma Y, Simms LA, Taylor KD, Whiteman D, 
Wijmenga C, Baldassano RN, Barclay M, Bayless TM, Brand S, Buning C, Cohen A, Colombel JF, Cottone M, Stronati L, Denson T, De Vos M, D'Inca R, Dubinsky M, Edwards C, Florin T, Franchimont D, Gearry R, Glas J, Van Gossum A, Guthery SL, Halfvarson J, Verspaget HW, Hugot JP, Karban A, Laukens D, Lawrance I, Lemann M, Levine A, Libioulle C, Louis E, Mowat C, Newman W, Panes J, Phillips A, Proctor DD, Regueiro M, Russell R, Rutgeerts P, Sanderson J, Sans M, Seibold F, Steinhart AH, Stokkers PC, Torkvist L, Kullak-Ublick G, Wilson D, Walters T, Targan SR, Brant SR, Rioux JD, D'Amato M, Weersma RK, Kugathasan S, Griffiths AM, Mansfield JC, Vermeire S, Duerr RH, Silverberg MS, Satsangi J, Schreiber S, Cho JH, Annese V, Hakonarson H, Daly MJ, Parkes M (2010) Genome-wide meta-analysis increases to 71 the number of confirmed Crohn's disease susceptibility loci. Nat Genet 42 (12):1118-1125

Fujiwara RT, Cancado GG, Freitas PA, Santiago HC, Massara CL, Dos Santos CO, Correa-Oliveira R, Geiger SM, Bethony J (2009) Necator americanus infection: a possible cause of altered dendritic cell differentiation and eosinophil profile in chronically infected individuals. PLoS Negl Trop Dis 3(3): e399

Fumagalli M, Pozzoli U, Cagliani R, Comi GP, Riva S, Clerici M, Bresolin N, Sironi M (2009) Parasites represent a major selective force for interleukin genes and shape the genetic predisposition to autoimmune conditions. J Exp Med 206(6):1395-1408. doi:10.1084/jem.20082779

Gordon S (2003) Alternative activation of macrophages. Nat Rev 3 (1):23-35

Gorelik L, Flavell RA (2000) Abrogation of TGFbeta signaling in T cells leads to spontaneous $\mathrm{T}$ cell differentiation and autoimmune disease. Immunity 12(2):171-181

Grainger JR, Smith KA, Hewitson JP, McSorley HJ, Harcus Y, Filbey KJ, Finney CA, Greenwood EJ, Knox DP, Wilson MS, Belkaid Y, Rudensky AY, Maizels RM (2010) Helminth secretions induce de novo T cell Foxp3 expression and regulatory function through the TGF-beta pathway. J Exp Med 207(11):2331-2341

Guan Q, Ma Y, Hillman CL, Qing G, Ma AG, Weiss CR, Zhou G, Bai A, Warrington RJ, Bernstein CN, Peng Z (2011) Targeting IL-12/ IL-23 by employing a p40 peptide-based vaccine ameliorates TNBS-induced acute and chronic murine colitis. Mol Med 17(78):646-656

Hall LJ, Faivre E, Quinlan A, Shanahan F, Nally K, Melgar S (2011) Induction and activation of adaptive immune populations during acute and chronic phases of a murine model of experimental colitis. Dig Dis Sci 56(1):79-89

Hang L, Setiawan T, Blum AM, Urban J, Stoyanoff K, Arihiro S, Reinecker HC, Weinstock JV (2010) Heligmosomoides polygyrus infection can inhibit colitis through direct interaction with innate immunity. J Immunol 185(6):3184-3189

Hartmann S, Kyewski B, Sonnenburg B, Lucius R (1997) A filarial cysteine protease inhibitor down-regulates $\mathrm{T}$ cell proliferation and enhances interleukin-10 production. Eur J Immunol 27 (9):2253-2260

Hartmann S, Schnoeller C, Dahten A, Avagyan A, Rausch S, Lendner M, Bocian C, Pillai S, Loddenkemper C, Lucius R, Worm M, Hamelmann E (2009) Gastrointestinal nematode infection interferes with experimental allergic airway inflammation but not atopic dermatitis. Clin Exp Allergy 39 (10):1585-1596

Herbert DR, Yang JQ, Hogan SP, Groschwitz K, Khodoun M, Munitz A, Orekov T, Perkins C, Wang Q, Brombacher F, Urban JF Jr, Rothenberg ME, Finkelman FD (2009) Intestinal epithelial cell secretion of RELM-beta protects against gastrointestinal worm infection. J Exp Med 206(13):2947-2957. doi:10.1084/ jem.20091268
Hogan SP, Seidu L, Blanchard C, Groschwitz K, Mishra A, Karow ML, Ahrens R, Artis D, Murphy AJ, Valenzuela DM, Yancopoulos GD, Rothenberg ME (2006) Resistin-like molecule beta regulates innate colonic function: barrier integrity and inflammation susceptibility. $\mathrm{J}$ Allergy Clin Immunol 118(1):257-268. doi:10.1016/j. jaci.2006.04.039

Hou JK, Abraham B, El-Serag H (2011) Dietary intake and risk of developing inflammatory bowel disease: a systematic review of the literature. Am J Gastroenterol 106(4):563-573

Huehn J, Siegmund K, Lehmann JC, Siewert C, Haubold U, Feuerer M, Debes GF, Lauber J, Frey O, Przybylski GK, Niesner U, de la Rosa M, Schmidt CA, Brauer R, Buer J, Scheffold A, Hamann A (2004) Developmental stage, phenotype, and migration distinguish naive- and effector/ memory-like CD4 \pm regulatory T cells. J Exp Med 199 (3):303-313. doi:10.1084/jem.20031562

Humphreys NE, Xu D, Hepworth MR, Liew FY, Grencis RK (2008) IL-33, a potent inducer of adaptive immunity to intestinal nematodes. J Immunol 180(4):2443-2449

Hunter MM, Wang A, Parhar KS, Johnston MJ, Van Rooijen N, Beck PL, McKay DM (2010) In vitro-derived alternatively activated macrophages reduce colonic inflammation in mice. Gastroenterology 138(4):1395-1405

Imaeda $\mathrm{H}$, Andoh A, Aomatsu T, Uchiyama K, Bamba S, Tsujikawa T, Naito Y, Fujiyama Y (2011) Interleukin-33 suppresses Notch ligand expression and prevents goblet cell depletion in dextran sulfate sodium-induced colitis. Int J Mol Med 28(4):573-578. doi:10.3892/ijmm.2011.718

Ince MN, Elliott DE, Setiawan T, Blum A, Metwali A, Wang Y, Urban JF Jr, Weinstock JV (2006) Heligmosomoides polygyrus induces TLR4 on murine mucosal T cells that produce TGFbeta after lipopolysaccharide stimulation. J Immunol 176 (2):726-729

Ince MN, Elliott DE, Setiawan T, Metwali A, Blum A, Chen HL, Urban JF, Flavell RA, Weinstock JV (2009) Role of T cell TGFbeta signaling in intestinal cytokine responses and helminthic immune modulation. Eur J Immunol 39(7):1870-1878

Izcue A, Coombes JL, Powrie F (2009) Regulatory lymphocytes and intestinal inflammation. Annu Rev Immunol 27:313-338

Khan WI, Blennerhasset PA, Varghese AK, Chowdhury SK, Omsted P, Deng Y, Collins SM (2002) Intestinal nematode infection ameliorates experimental colitis in mice. Infect Immun 70 (11):5931-5937

Kitagaki K, Businga TR, Racila D, Elliott DE, Weinstock JV, Kline JN (2006) Intestinal helminths protect in a murine model of asthma. J Immunol 177(3):1628-1635

Klotz C, Ziegler T, Figueiredo AS, Rausch S, Hepworth MR, Obsivac N, Sers C, Lang R, Hammerstein P, Lucius R, Hartmann S (2011) A helminth immunomodulator exploits host signaling events to regulate cytokine production in macrophages. PLoS Pathogens 7 (1):e1001248

Kradin RL, Badizadegan K, Auluck P, Korzenik J, Lauwers GY (2006) Iatrogenic Trichuris suis infection in a patient with Crohn disease. Arch Pathol Lab Med 130(5):718-720

Kreider T, Anthony RM, Urban JF Jr, Gause WC (2007) Alternatively activated macrophages in helminth infections. Curr Opin Immunol 19(4):448-453

Krimi RB, Kotelevets L, Dubuquoy L, Plaisancie P, Walker F, Lehy T, Desreumaux P, Van Seuningen I, Chastre E, ForgueLafitte ME, Marie JC (2008) Resistin-like molecule beta regulates intestinal mucous secretion and curtails TNBSinduced colitis in mice. Inflamm Bowel Dis 14(7):931-941. doi:10.1002/ibd.20420

Kuhn R, Lohler J, Rennick D, Rajewsky K, Muller W (1993) Interleukin-10-deficient mice develop chronic enterocolitis. Cell $75(2): 263-274$ 
Li Z, Liu G, Chen Y, Liu Y, Liu B, Su Z (2011) The phenotype and function of naturally existing regulatory dendritic cells in nematode-infected mice. Int J Parasitol 49(11):1129-1137

Liu H, Komai-Koma M, Xu D, Liew FY (2006) Toll-like receptor 2 signaling modulates the functions of $\mathrm{CD} 4 \pm \mathrm{CD} 25 \pm$ regulatory $\mathrm{T}$ cells. Proc Natl Acad Sci U S A 103(18):7048-7053

Loke P, Gallagher I, Nair MG, Zang X, Brombacher F, Mohrs M, Allison JP, Allen JE (2007) Alternative activation is an innate response to injury that requires $\mathrm{CD} 4 \pm \mathrm{T}$ cells to be sustained during chronic infection. J Immunol 179(6):39263936

MacDonald AS, Maizels RM (2008) Alarming dendritic cells for Th2 induction. J Exp Med 205(1):13-17

Maizels RM, Balic A, Gomez-Escobar N, Nair M, Taylor MD, Allen JE (2004) Helminth parasites - masters of regulation. Immunol Rev 201:89-116

Manoury B, Gregory WF, Maizels RM, Watts C (2001) Bm-CPI-2, a cystatin homolog secreted by the filarial parasite Brugia malayi, inhibits class II MHC-restricted antigen processing. Curr Biol 11 (6):447-451

Massacand JC, Stettler RC, Meier R, Humphreys NE, Grencis RK, Marsland BJ, Harris NL (2009) Helminth products bypass the need for TSLP in Th2 immune responses by directly modulating dendritic cell function. Proc Natl Acad Sci U S A 106 (33):13968-13973

Matera G, Giancotti A, Scalise S, Pulicari MC, Maselli R, Piizzi C, Pelaia G, Tancre V, Muto V, Doldo P, Cosco V, Cosimo P, Capicotto R, Quirino A, Scalzo R, Liberto MC, Parlato G, Foca A (2008) Ascaris lumbricoides-induced suppression of total and specific IgE responses in atopic subjects is interleukin 10independent and associated with an increase of $\mathrm{CD} 25( \pm)$ cells. Diagn Microbiol Infect Dis 62(3):280-286

McSorley HJ, Harcus YM, Murray J, Taylor MD, Maizels RM (2008) Expansion of Foxp3 \pm regulatory $\mathrm{T}$ cells in mice infected with the filarial parasite Brugia malayi. J Immunol 181(9):6456-6466

Metenou S, Dembele B, Konate S, Dolo H, Coulibaly SY, Coulibaly YI, Diallo AA, Soumaoro L, Coulibaly ME, Sanogo D, Doumbia SS, Traore SF, Mahanty S, Klion A, Nutman TB (2010) At homeostasis filarial infections have expanded adaptive $\mathrm{T}$ regulatory but not classical Th2 cells. J Immunol 184(9):5375-5382

Metwali A, Setiawan T, Blum AM, Urban J, Elliott DE, Hang L, Weinstock JV (2006) Induction of CD8 \pm regulatory T cells in the intestine by Heligmosomoides polygyrus infection. Am J Physiol 291(2):G253-G259

Monteleone G, Boirivant M, Pallone F, MacDonald TT (2008) TGFbeta1 and Smad7 in the regulation of IBD. Mucosal Immunol 1 (Suppl 1):S50-S53. doi:10.1038/mi.2008.55

Montes M, Sanchez C, Verdonck K, Lake JE, Gonzalez E, Lopez G, Terashima A, Nolan T, Lewis DE, Gotuzzo E, White AC $\mathrm{Jr}$ (2009) Regulatory $\mathrm{T}$ cell expansion in HTLV-1 and strongyloidiasis co-infection is associated with reduced IL-5 responses to Strongyloides stercoralis antigen. PLoS Negl Trop Dis 3(6): 456

Motomura Y, Wang H, Deng Y, El-Sharkawy RT, Verdu EF, Khan WI (2009) Helminth antigen-based strategy to ameliorate inflammation in an experimental model of colitis. Clin Exp Immunol 155 (1):88-95

Mucida D, Park Y, Kim G, Turovskaya O, Scott I, Kronenberg M, Cheroutre H (2007) Reciprocal TH17 and regulatory T cell differentiation mediated by retinoic acid. Science (New York, NY) 317(5835):256-260

Murai M, Turovskaya O, Kim G, Madan R, Karp CL, Cheroutre H, Kronenberg M (2009) Interleukin 10 acts on regulatory T cells to maintain expression of the transcription factor Foxp3 and suppressive function in mice with colitis. Nat Immunol 10 (11):1178-1184

Murray J, Manoury B, Balic A, Watts C, Maizels RM (2005) Bm-CPI2, a cystatin from Brugia malayi nematode parasites, differs from Caenorhabditis elegans cystatins in a specific site mediating inhibition of the antigen-processing enzyme AEP. Mol Biochem Parasitol 139(2):197-203

Mylonas KJ, Nair MG, Prieto-Lafuente L, Paape D, Allen JE (2009) Alternatively activated macrophages elicited by helminth infection can be reprogrammed to enable microbial killing. J Immunol 182(5):3084-3094

Neurath M, Fuss I, Strober W (2000) TNBS-colitis. Int Rev Immunol 19(1):51-62

Niess JH (2008) Role of mucosal dendritic cells in inflammatory bowel disease. World J Gastroenterol 14(33):5138-5148

Niess JH, Brand S, Gu X, Landsman L, Jung S, McCormick BA, Vyas JM, Boes M, Ploegh HL, Fox JG, Littman DR, Reinecker HC (2005) CX3CR1-mediated dendritic cell access to the intestinal lumen and bacterial clearance. Science 307(5707):254-258. doi:10.1126/science. 1102901

Pfaff AW, Schulz-Key H, Soboslay PT, Taylor DW, MacLennan K, Hoffmann WH (2002) Litomosoides sigmodontis cystatin acts as an immunomodulator during experimental filariasis. Int $\mathbf{J}$ Parasitol 32(2):171-178

Potian JA, Rafi W, Bhatt K, McBride A, Gause WC, Salgame P (2011) Preexisting helminth infection induces inhibition of innate pulmonary anti-tuberculosis defense by engaging the IL-4 receptor pathway. J Exp Med 208(9):1863-1874

Price AE, Liang HE, Sullivan BM, Reinhardt RL, Eisley CJ, Erle DJ, Locksley RM (2010) Systemically dispersed innate IL-13expressing cells in type 2 immunity. Proc Natl Acad Sci U S A 107(25):11489-11494. doi:10.1073/pnas.1003988107

Pulendran B, Tang H, Manicassamy S (2010) Programming dendritic cells to induce $\mathrm{T}(\mathrm{H}) 2$ and tolerogenic responses. Nat Immunol 11 (8):647-655

Qualls JE, Kaplan AM, van Rooijen N, Cohen DA (2006) Suppression of experimental colitis by intestinal mononuclear phagocytes. J Leukoc Biol 80(4):802-815

Rausch S, Huehn J, Kirchhoff D, Rzepecka J, Schnoeller C, Pillai S, Loddenkemper C, Scheffold A, Hamann A, Lucius R, Hartmann S (2008) Functional analysis of effector and regulatory $\mathrm{T}$ cells in a parasitic nematode infection. Infect Immun 76(5):1908-1919

Rausch S, Huehn J, Loddenkemper C, Hepworth MR, Klotz C, Sparwasser T, Hamann A, Lucius R, Hartmann S (2009) Establishment of nematode infection despite increased Th2 responses and immunopathology after selective depletion of Foxp3 \pm cells. Eur J Immunol 39(11):3066-3077

Reece JJ, Siracusa MC, Southard TL, Brayton CF, Urban JF Jr, Scott AL (2008) Hookworm-induced persistent changes to the immunological environment of the lung. Infect Immun 76(8):3511-3524

Rimoldi M, Chieppa M, Salucci V, Avogadri F, Sonzogni A, Sampietro GM, Nespoli A, Viale G, Allavena P, Rescigno M (2005) Intestinal immune homeostasis is regulated by the crosstalk between epithelial cells and dendritic cells. Nat Immunol 6 (5):507-514. doi:10.1038/ni1192

Rizzo A, Monteleone I, Fina D, Stolfi C, Caruso R, Fantini MC, Franze E, Schwendener R, Pallone F, Monteleone G (2011) Inhibition of colitis by IL-25 associates with induction of alternatively activated macrophages. Inflammatory Bowel Diseases. doi:10.1002/ibd.21799

Rubtsov YP, Rasmussen JP, Chi EY, Fontenot J, Castelli L, Ye X, Treuting P, Siewe L, Roers A, Henderson WR Jr, Muller W, Rudensky AY (2008) Regulatory T cell-derived interleukin-10 limits inflammation at environmental interfaces. Immunity 28 (4):546-558. doi:10.1016/j.immuni.2008.02.017 
Ruyssers NE, De Winter BY, De Man JG, Loukas A, Pearson MS, Weinstock JV, Van den Bossche RM, Martinet W, Pelckmans PA, Moreels TG (2009) Therapeutic potential of helminth soluble proteins in TNBS-induced colitis in mice. Inflamm Bowel Dis 15 (4):491-500. doi:10.1002/ibd.20787

Saenz SA, Taylor BC, Artis D (2008) Welcome to the neighborhood: epithelial cell-derived cytokines license innate and adaptive immune responses at mucosal sites. Immunol Rev 226:172-190

Satoguina J, Mempel M, Larbi J, Badusche M, Loliger C, Adjei O, Gachelin G, Fleischer B, Hoerauf A (2002) Antigen-specific T regulatory-1 cells are associated with immunosuppression in a chronic helminth infection (onchocerciasis). Microbe infect/ Institut Pasteur 4(13):1291-1300

Scheiffele F, Fuss IJ (2002) Induction of TNBS colitis in mice. In: Coligan JE (ed) Current protocols in immunology. Wiley, New York, Chapter 15:Unit 15.19

Schierack P, Lucius R, Sonnenburg B, Schilling K, Hartmann S (2003) Parasite-specific immunomodulatory functions of filarial cystatin. Infect Immun 71(5):2422-2429

Schnoeller C, Rausch S, Pillai S, Avagyan A, Wittig BM, Loddenkemper C, Hamann A, Hamelmann E, Lucius R, Hartmann S (2008) A helminth immunomodulator reduces allergic and inflammatory responses by induction of IL-10producing macrophages. J Immunol 180(6):4265-4272

Schonemeyer A, Lucius R, Sonnenburg B, Brattig N, Sabat R, Schilling K, Bradley J, Hartmann S (2001) Modulation of human $\mathrm{T}$ cell responses and macrophage functions by onchocystatin, a secreted protein of the filarial nematode Onchocerca volvulus. J Immunol 167(6):3207-3215

Schopf L, Luccioli S, Bundoc V, Justice P, Chan CC, Wetzel BJ, Norris HH, Urban JF Jr, Keane-Myers A (2005) Differential modulation of allergic eye disease by chronic and acute ascaris infection. Investig Ophthalmol Vis Sci 46(8):2772-2780. doi:10.1167/iovs.04-0899

Segura M, Su Z, Piccirillo C, Stevenson MM (2007) Impairment of dendritic cell function by excretory-secretory products: a potential mechanism for nematode-induced immunosuppression. Eur J Immunol 37(7):1887-1904

Seidelin JB, Rogler G, Nielsen OH (2011) A role for interleukin-33 in $\mathrm{T}(\mathrm{H}) 2$-polarized intestinal inflammation? Mucosal Immunol 4 (5):496-502. doi:10.1038/mi.2011.22

Setiawan T, Metwali A, Blum AM, Ince MN, Urban JF Jr, Elliott DE, Weinstock JV (2007) Heligmosomoides polygyrus promotes regulatory T-cell cytokine production in the murine normal distal intestine. Infect Immun 75(9):4655-4663

Siracusa MC, Reece JJ, Urban JF Jr, Scott AL (2008) Dynamics of lung macrophage activation in response to helminth infection. $\mathrm{J}$ Leukoc Biol 84(6):1422-1433

Smith KA, Hochweller K, Hammerling GJ, Boon L, MacDonald AS, Maizels RM (2011) Chronic helminth infection promotes immune regulation in vivo through dominance of CD11 cloCD103- dendritic cells. J Immunol 186(12):7098-7109

Specht S, Volkmann L, Wynn T, Hoerauf A (2004) Interleukin-10 (IL10) counterregulates IL-4-dependent effector mechanisms in murine filariasis. Infect Immun 72(11):6287-6293. doi:10.1128/ IAI.72.11.6287-6293.2004

Stephenson LS, Latham MC, Ottesen EA (2000) Malnutrition and parasitic helminth infections. Parasitology 121(Suppl):S23S38

Strachan DP (1989) Hay fever, hygiene, and household size. BMJ 299 (6710):1259-1260

Summers RW, Elliott DE, Qadir K, Urban JF Jr, Thompson R, Weinstock JV (2003) Trichuris suis seems to be safe and possibly effective in the treatment of inflammatory bowel disease. Am J Gastroenterol 98(9):2034-2041

Summers RW, Elliott DE, Urban JF Jr, Thompson RA, Weinstock JV (2005) Trichuris suis therapy for active ulcerative colitis: a randomized controlled trial. Gastroenterology 128 (4):825-832

Sutton TL, Zhao A, Madden KB, Elfrey JE, Tuft BA, Sullivan CA, Urban JF Jr, Shea-Donohue T (2008) Anti-inflammatory mechanisms of enteric Heligmosomoides polygyrus infection against trinitrobenzene sulfonic acid-induced colitis in a murine model. Infect Immun 76(10):4772-4782

Taylor BC, Zaph C, Troy AE, Du Y, Guild KJ, Comeau MR, Artis D (2009) TSLP regulates intestinal immunity and inflammation in mouse models of helminth infection and colitis. J Exp Med 206 (3):655-667

Tetsutani K, Ishiwata K, Ishida $\mathrm{H}$, Tu L, Torii M, Hamano S, Himeno K, Hisaeda H (2009) Concurrent infection with Heligmosomoides polygyrus suppresses anti-Plasmodium yoelii protection partially by induction of CD4( \pm CD25( \pm Foxp3( $( \pm)$ Treg in mice. Eur J Immunol 39(10):2822-2830

van Heel DA, Udalova IA, De Silva AP, McGovern DP, Kinouchi Y, Hull J, Lench NJ, Cardon LR, Carey AH, Jewell DP, Kwiatkowski D (2002) Inflammatory bowel disease is associated with a TNF polymorphism that affects an interaction between the OCT1 and NF(-kappa)B transcription factors. Hum Mol Genet 11(11):12811289

Weisser SB, Brugger HK, Voglmaier NS, McLarren KW, van Rooijen N, Sly LM (2011) SHIP-deficient, alternatively activated macrophages protect mice during DSS-induced colitis. J Leukoc Biol 90(3):483-492

Wilson MS, Taylor MD, Balic A, Finney CA, Lamb JR, Maizels RM (2005) Suppression of allergic airway inflammation by helminthinduced regulatory T cells. J Exp Med 202(9):1199-1212

Wilson MS, Ramalingam TR, Rivollier A, Shenderov K, MentinkKane MM, Madala SK, Cheever AW, Artis D, Kelsall BL, Wynn TA (2011) Colitis and intestinal inflammation in IL10-/- mice results from IL-13Ralpha2-mediated attenuation of IL-13 activity. Gastroenterology 140(1):254-264

Xavier RJ, Podolsky DK (2007) Unravelling the pathogenesis of inflammatory bowel disease. Nature 448(7152):427-434. doi:10.1038/nature06005

Yamazaki S, Dudziak D, Heidkamp GF, Fiorese C, Bonito AJ, Inaba K, Nussenzweig MC, Steinman RM (2008) CD8 \pm CD205 \pm splenic dendritic cells are specialized to induce Foxp $3 \pm$ regulatory T cells. J Immunol 181(10):6923-6933 